\title{
A Listed Company Evaluation Based on DCF Model- the Case of Medical Apparatus and Instruments Industry
}

\author{
Luyao Cheng ${ }^{1, \mathrm{a}}$
}

\author{
${ }^{1}$ Business, Economics and Law of The University of Queensland \\ ${ }^{a}$ Email:chengluyaocareer@163.com
}

\begin{abstract}
This study pays attention to Johnson\&Johnson, which is one of the companies in the medical devices industry that a highly specialized industry with deep growth prospects to examines its enterprise value through the discount the free cash flow for the firm model. The Author conducts comprehensive research that mainly finds its result of operations, liquidity and cash flows using accounting formulas to figure out cash flow from operations and free cash flow for the firm. The paper also demonstrates how to get the weighted average cost of capital by financing data such as interest expense and dividend. Finally, it can calculate the intrinsic value through discount free cash flow by discount capital and determine whether the difference exists between the calculating result and current share price on the market.
\end{abstract}

Keywords: Johnson\&Johnson, Medical Devices, Enterprise value, Free cash flow, Cost of capital

\section{INTRODUCTION}

As a new industry involving medicine, machinery, electronics, plastics, and other fields, the medical device industry is considered a multidisciplinary, knowledgeintensive, capital-intensive industry. The medical device industry has more room for development. Consumption attributes can be widely used in orthopaedics, ophthalmology, dentistry, rehabilitation, medical beauty, and other industries, such as home commonly used temperature gun, blood pressure meter, blood glucose meter, and have consumption properties. In general, stocks with consumer attributes are more likely to form barriers and may form premiums in the secondary market. Therefore, compared to pharmaceutical stocks, it is easier to get a premium. Therefore, as a cross-field modern high-technology, its products are directly or indirectly used on the human body with high technology and high profits characteristics. As a result, significant countries as a critical industry have vigorously developed it.

As investors increasingly value listed medical device companies, DCF technology is used to estimate the company's value. More specifically, researchers use the company's free cash flow rather than equity-free cash flow because it is available to all fund providers and can explain how much cash "business operations" generate for capital providers (equity and debt)? All necessary investments in working capital and fixed capital after tax have been completed. Bodie, Z., Kane, A., \& Marcus, A. J. (2012) explained that this approach is to discount the free cash flow for the firm at the weighted average cost of capital to obtain to find the value of equity [1].

\section{LITERATURE REVIEW}

A survey of financial practitioners in European countries by Franck Bancel, ESCP Europe-Labex ReFi and Usha R. Mittoo (2014) shows two common approaches, namely cash flow discounting and its variants and relative valuation frameworks, such as the price-to-earnings ratio of peer conglomerates in the same industry [2]. Lucio Cassia, Andrea Plati, Silvio Vismara (2007) pointed that the two-stage DCF model was the most frequent that the first stage is a period of explicit forecast, while the second stage assumes that the cash flows grow at a constant perpetual growth rate. The value after the explicit forecast period is referred to as the Terminal Value or the continuing value. This Terminal Value typically accounts for a large part of the estimated Enterprise Value [3]. Pablo Fernández (2011) makes some common errors in calculating WACC, such as using the carrying value of debt and equity to calculate the operating costs of debt and equity [4]. Saha and Malkiel, (2015) proposed the limitation that $\beta$ is difficult 
to measure especially in the true market portfilo without any precision [5]. Van (2010) thought that the cost of being "overlevered" can provide insights into the potential cost of financial distress [6]. However, there are few references to the valuation of listed companies in the medical device and even healthcare industry using the DCF model.

\section{RESEARCH METHODOLOGY}

This paper selects the two-stage DCF model to analyse. The formula is shown as below:

Firm value $=\sum_{\mathrm{t}=1}^{\mathrm{n}} \frac{\mathrm{FCFF}_{\mathrm{t}}}{(1+\mathrm{WACC})_{\mathrm{t}}}+\frac{\mathrm{FCFF}_{\mathrm{n}+1}}{(\mathrm{WACC}-\mathrm{g})} \times \frac{1}{(1+\mathrm{WACC})^{\mathrm{n}}}$

Firstly, the two-stage free cash flow model is a method of discounted valuation of the company's future free cash flow, which is similar to the two-stage dividend discount model. Precisely, the two-stage cash flow model consists of two periods, and it is most common in practice to assume that free cash will go through two stages of growth. In the first phase, these cash flows grow at a constant rate for several years. In the second phase, assume that cash flow will grow at different rates over the remainder of the period, which is essentially similar to the Gordon growth model.

$\mathrm{FCFF}=\mathrm{NI}+\mathrm{NCC}+\operatorname{Int}(1-\mathrm{Tax}$ rate $)-$ FCInv - WCInv

FCFF $=$ CFO $+\operatorname{Int}(1-$ Tax rate $)-$ FCInv

Secondly, this step involves getting the accurate free cash flow in the company's financial statement. There are three types of free cash flow: free cash flow to the firm, free cash flow to equity and dividends. However, FCFF considers all the capital suppliers of the firms, including common shareholders, preferred shareholders, and creditors. Therefore it provides comprehensive perspectives to consider the intrinsic value of a company. In addition, FCFF can be explained that is after-tax cash flow that a company can distribute to all investors after paying all operating expenses and making the necessary investment in fixed assets and operating assets, so the equation (2) and (3) is one of the approaches to calculate free cash flow to the firm.

$$
\begin{aligned}
& W A C C=\frac{M V(\text { Debt })}{\begin{array}{c}
M V(\text { Debt })+M V(E q u i t y) \\
M V(E q u i t y)
\end{array}} r_{d}(1-\text { Tax rate })+ \\
& \frac{M V(\text { Equity })}{M V(\text { Debt })+M V(\text { Equity })} r_{e} \\
& C M V=\frac{D P S}{C C E-G R D}
\end{aligned}
$$

$$
\begin{gathered}
R_{e}=\text { Cost of Equity }=\frac{D P S}{C M V}+G R D \\
R_{d}=\text { Cost of Debt }=\frac{\text { Total interest }}{\text { Total debt }}
\end{gathered}
$$

Thirdly, the discount rate is also a critical step in valuation. The discount rate is called the weighted average cost of capital, which is the sum of the weighted debt cost and the weighted equity cost, so equation (4) can be used to calculate WACC. It is worth noting that the proportion of debt financing can be used to offset taxes, so we need to subtract the effective tax rate when calculating the cost of debt. It is worth noting that the equation uses market value rather than book value because market value reflects the expected capital structure, not the past and present. In addition, the CAPM model is a classic technique when it comes to acquiring equity costs, but if it is a dividend company, the dividend capitalization model (deformation of the DDM model) is more direct [as shown in equation (5) and (6)]. In addition, the cost of debt can be found in equation (7). The results can be calculated using the above equations (1) to (7).

\section{EMPIRICAL CASE ANALYSIS}

This article selects Johnson and Johnson (J-J) as its case study, and it is a perfect healthcare company, unlike G.E., which is committed to producing medical devices. At the same time, through multi-sector operations and finance such as aviation, renewable energy and venture capital, the data in G.E.'s annual report does not directly reflect the performance of the medical device industry. In addition, founded in 1886 and now 135 years old, Johnson and Johnson are one of the world's most valuable companies, ranking 36th on the List of Fortune 500 U.S. companies by gross revenue in 2021. In addition, cutting-edge eyeglasses and other medical devices are popular with young people, knee and shoulder replacement surgery is widely used in operating theatres. Therefore, whether from the economic strength, development process, or brand influence, Johnson and Johnson are a representative company.

Table 1 Growth rate of Sales and CFO of J\&J from 2016 to 2020

\begin{tabular}{|l|l|l|l|l|l|l|}
\hline Year & 2016 & 2017 & 2018 & 2019 & 2020 & $\begin{array}{l}\text { Foreca } \\
\text { st }\end{array}$ \\
\hline Sales & $2.59 \%$ & $6.34 \%$ & $6.71 \%$ & $0.59 \%$ & $0.64 \%$ & $1.00 \%$ \\
\hline CFO & $-2.59 \%$ & $12.23 \%$ & $5.21 \%$ & $5.41 \%$ & $0.49 \%$ & $2.50 \%$ \\
\hline
\end{tabular}

Table 2 The calculation of historical FCFF of J\&J

\begin{tabular}{|l|l|l|l|l|l|l|l|l|l|l|}
\hline Year & \multicolumn{2}{|l|}{2016} & \multicolumn{2}{l|}{2017} & \multicolumn{2}{l|}{2018} & \multicolumn{2}{l|}{2019} \\
\hline $\begin{array}{l}\text { Sales to } \\
\text { customers }\end{array}$ & 71890 & $100 \%$ & 76450 & $100 \%$ & 81581 & $100 \%$ & 82059 & $100 \%$ & 82584 & $100 \%$ \\
\hline Add: Net income & 16540 & $23.01 \%$ & 1300 & $1.70 \%$ & 15297 & $18.75 \%$ & 15119 & $18.42 \%$ & 14714 & $17.82 \%$ \\
\hline $\begin{array}{l}\text { Add: Net noncash } \\
\text { charges }\end{array}$ & 4900 & $6.82 \%$ & 9800 & $12.82 \%$ & 9200 & $8.46 \%$ & 9100 & $11.10 \%$ & 6100 & $7.39 \%$ \\
\hline
\end{tabular}




\begin{tabular}{|l|l|l|l|l|l|l|l|l|l|l|}
\hline $\begin{array}{l}\text { Less: Working } \\
\text { capital investment }\end{array}$ & 2640 & $3.67 \%$ & -10000 & $13.08 \%$ & 2297 & $2.82 \%$ & 1119 & $1.36 \%$ & -2700 & $-3.27 \%$ \\
\hline $\begin{array}{l}\text { Cash flow from } \\
\text { operations }\end{array}$ & $\mathbf{1 8 8 0 0}$ & $\mathbf{2 6 . 1 5 \%}$ & $\mathbf{2 1 1 0 0}$ & $\mathbf{2 7 . 6 0 \%}$ & $\mathbf{2 2 2 0 0}$ & $\mathbf{2 7 . 2 1 \%}$ & $\mathbf{2 3 4 0 0}$ & $\mathbf{2 8 . 5 2 \%}$ & $\mathbf{2 3 5 1 4}$ & $\mathbf{2 8 . 4 7 \%}$ \\
\hline Interest expense & 730 & $1.02 \%$ & 960 & $1.26 \%$ & 1049 & $1.29 \%$ & 995 & $1.21 \%$ & 904 & $1.09 \%$ \\
\hline Effective tax rate & $16.5 \%$ & $/$ & $92.6 \%$ & $/$ & $15 \%$ & $/$ & $12.7 \%$ & $/$ & $10.8 \%$ & $/$ \\
\hline $\begin{array}{l}\text { Add: Interest } \\
\text { expense after tax }\end{array}$ & $\mathbf{6 0 9 . 5 5}$ & $\mathbf{0 . 8 5 \%}$ & $\mathbf{7 1 . 0 4}$ & $\mathbf{0 . 0 9 \%}$ & $\mathbf{8 9 1 . 6 5}$ & $\mathbf{1 . 0 9 \%}$ & $\mathbf{8 6 8 . 6 4}$ & $\mathbf{1 . 0 6 \%}$ & $\mathbf{8 0 6 . 3 7}$ & $\mathbf{0 . 9 8 \%}$ \\
\hline $\begin{array}{l}\text { Less: Capital } \\
\text { expenditure }\end{array}$ & $\mathbf{3 2 0 0}$ & $\mathbf{4 . 4 5 \%}$ & $\mathbf{3 3 0 0}$ & $\mathbf{4 . 3 2 \%}$ & $\mathbf{3 7 0 0}$ & $\mathbf{4 . 5 4 \%}$ & $\mathbf{3 5 0 0}$ & $\mathbf{4 . 2 7 \%}$ & $\mathbf{3 3 0 0}$ & $\mathbf{3 . 9 6 \%}$ \\
\hline $\begin{array}{l}\text { Free Cash Flow } \\
\text { for Firm }\end{array}$ & $\mathbf{1 6 2 0 9 . 5 5}$ & $\mathbf{2 2 . 5 5 \%}$ & $\mathbf{1 7 8 7 1 . 0 4}$ & $\mathbf{2 3 . 3 8 \%}$ & $\mathbf{1 9 3 9 1 . 6 5}$ & $\mathbf{2 3 . 7 7 \%}$ & $\mathbf{2 0 7 6 8 . 6 4}$ & $\mathbf{2 5 . 3 1 \%}$ & $\mathbf{2 1 0 2 0 . 3 7}$ & $\mathbf{2 5 . 4 5 \%}$ \\
\hline
\end{tabular}

Table 3 The calculation of forecast FCFF of J\&J

\begin{tabular}{|c|c|c|c|c|c|c|c|c|c|c|}
\hline Year & \multicolumn{2}{|l|}{2021} & \multicolumn{2}{|l|}{2022} & \multicolumn{2}{|l|}{2023} & \multicolumn{2}{|l|}{2024} & \multicolumn{2}{|l|}{2025} \\
\hline $\begin{array}{l}\text { Sales to } \\
\text { customers }\end{array}$ & 83410 & $100 \%$ & 84244 & $100 \%$ & 85086 & $100 \%$ & 85937 & $100 \%$ & 86797 & $100 \%$ \\
\hline $\begin{array}{l}\text { Cash flow from } \\
\text { operations }\end{array}$ & 24102 & $28.90 \%$ & 24704 & $29.32 \%$ & 25322 & $29.76 \%$ & 25955 & $30.20 \%$ & 26604 & $30.65 \%$ \\
\hline Interest expense & 975.90 & $1.17 \%$ & 985.65 & $1.17 \%$ & 995.51 & $1.17 \%$ & 1005.46 & $1.17 \%$ & 1015.52 & $1.17 \%$ \\
\hline Effective tax rate & $13.8 \%$ & I & $13.8 \%$ & 1 & $13.8 \%$ & 1 & $13.8 \%$ & I & $13.8 \%$ & I \\
\hline $\begin{array}{l}\text { Add: Interest } \\
\text { expense after tax }\end{array}$ & 841.23 & $1.01 \%$ & 849.63 & $1.01 \%$ & 858.13 & $1.01 \%$ & 866.71 & $1.01 \%$ & 875.38 & $1.01 \%$ \\
\hline $\begin{array}{l}\text { Less: Capital } \\
\text { expenditure }\end{array}$ & 3600 & $4.31 \%$ & 3600 & $4.31 \%$ & 3700 & $4.31 \%$ & 3700 & $4.31 \%$ & 3700 & $4.31 \%$ \\
\hline $\begin{array}{l}\text { Free Cash Flow } \\
\text { for Firm }\end{array}$ & 21343.23 & $25.59 \%$ & 21953.63 & $26.06 \%$ & 22480.13 & $26.42 \%$ & 23121.71 & $26.91 \%$ & 23779.38 & $27.40 \%$ \\
\hline
\end{tabular}

According to equations 2 and 3, the cash flow equals net earnings plus net noncash charges less working capital investment. Net noncash flow is a relatively complex component that contains depreciation, amortization, deferred tax, gain and less, and restructuring charges, and the working capital could be available by current asset minus current liabilities. After knowing the result of cash flow of operation and the last component capital expenditure means the change of property, plant, and equipment, the free cash flow can be calculated. Hence, Table 2 provides feature values that affect FCFF and shows the percentage of total sales (vertical analysis). In addition, the growth rate of the influencing factors for the year 2016-2020 is conducive to our analysis of trends in the various factors (horizontal analysis).

Then, from all these above, the expected CFO, interest, capital expenditure and free cash flow for the firm from 2021 to 2025 could be forecasted evidently. Firstly, in terms of sales to customers, from table 1, we can learn that the growth rate presents an upward and then downward trend. Besides, according to the 2020 annual report interpretation, J\&J faces substantial competition in all geographic markets because of technological innovations, intellectual property rights, product performance, real or perceived product advantages, pricing and availability and rate of reimbursement. Competitors' development of more effective or less costly products, and their ability to secure patent and other intellectual property rights and successfully market products ahead of the company, could negatively impact sales of the company's existing products as well as its ability to bring new products to market despite significant prior investment in the related product development. As a result, annual sales to customers will continue to grow at a steady rate of $1 \%$. Second, for CFOs, the researchers forecast growth of $2.5 \%$. Third, interest expense as a percentage of sales is relatively flat, so the researchers took the average of these five figures $(1.02 \%, 1.26 \%, 1.29 \%, 1.21 \%, 1.09 \%)$ $(1.17 \%)$, and then the average percentage was available. In addition, the particular circumstances of the Tax Cuts and Employment Act (TCJA) are expected to be enacted in the United States in 2017, resulting in the revaluation of the Company's U.S.-related deferred income tax assets and liabilities, with an impact on the effective tax rate. The rest of the year fluctuated only slightly, so the researchers also took a four-year average so they could calculate after-tax interest charges (13.8\%). In addition, capital expenditure fluctuated slightly, using the average growth rate for the five years (4.31 per cent) directly as a follow-up year, with capital expenditures expected to be rounded to the nearest 100. Finally, based on equation (3), the prediction can be obtained. 
Table 4 The calculation of Capital Structure of J\&J

\begin{tabular}{|c|c|c|c|c|c|}
\hline Year & 2016 & 2017 & 2018 & 2019 & 2020 \\
\hline CSO & 2713346602 & 2682901553 & 2663138579 & 2634721257 & 2628679824 \\
\hline $\begin{array}{c}\text { Equity } \\
\text { capital }\end{array}$ & 312604.66 & 374855.01 & 338937.65 & 384010.62 & 406183.61 \\
\hline Debt capital & 23500 & 30900 & 32500 & 29100 & 31500 \\
\hline Total & 336104.66 & 405755.01 & 371437.65 & 413110.62 & 437683.61 \\
\hline
\end{tabular}

Table 5 Cost of Capital of J\&J

\begin{tabular}{|c|c|c|c|c|c|}
\hline Year & 2016 & 2017 & 2018 & 2019 & 2020 \\
\hline DPS & 3.32 & 3.54 & 3.75 & 3.98 & 4.21 \\
\hline GRD & $5.40 \%$ & $6.63 \%$ & $5.93 \%$ & $6.13 \%$ & $5.78 \%$ \\
\hline CMV & 115.21 & 139.72 & 127.27 & 145.75 & 154.52 \\
\hline Re & $8.28 \%$ & $9.16 \%$ & $8.88 \%$ & $8.86 \%$ & $8.50 \%$ \\
\hline Interest & 730 & 960 & 1049 & 995 & 904 \\
\hline Rd & $3.11 \%$ & $3.11 \%$ & $3.28 \%$ & $3.42 \%$ & $2.87 \%$ \\
\hline $\begin{array}{c}\text { Effective tax } \\
\text { rate }\end{array}$ & $2.60 \%$ & $0.23 \%$ & $2.79 \%$ & $2.99 \%$ & $2.56 \%$ \\
\hline $\begin{array}{l}\text { WACC } \\
\text { Average }\end{array}$ & $7.88 \%$ & $8.48 \%$ & $8.35 \%$ & $8.45 \%$ & $8.07 \%$ \\
\hline \multicolumn{2}{|r|}{} \\
\hline
\end{tabular}

Table 4 and 5 are the process of the calculating weighted average cost of capital. Specifically, equations (6) and (7) are used to determine the cost of equity and debt. Finally, the intrinsic value of the enterprise can be worked out as below:

$$
\begin{aligned}
& \text { Enterprise Value }=\frac{21,343.23}{(1+8.25 \%)^{1}}+\frac{21,953.63}{(1+8.25 \%)^{2}}+ \\
& \frac{22,480.13}{(1+8.25 \%)^{3}}+\frac{23,121.71}{(1+8.25 \%)^{4}}+\frac{(23,779.38) /(8.50 \%-5.78 \%)}{(1+8.25 \%)^{5}}= \\
& \text { 661,167.67 (dollars in million) } \\
& \text { Equity Value }=\text { Enterprise value }- \text { Debt value } \\
& =661,167.67-31,500 \\
& =629,667.67 \text { (dollars in million) }
\end{aligned}
$$

Stock price per share

$$
\begin{aligned}
& =\frac{\text { Equity Value }}{\text { Common Stock outstanding }} \\
& =\frac{629,667.67 \times 1,000,000}{2,628,679,824} \\
& =239.54(\text { dollars })
\end{aligned}
$$

\section{CONCLUSION}

The purpose of the paper is to evaluate the intrinsic value through comprehensive research, including understanding the industrial background, summarizing referenceable approaches from present literature, selecting formulas, and analyzing financial reports of J\&J. From its financial reports, Johnson and Johnson are excited about the great potential of the end-to-end digital surgical ecosystem and is developing three differentiated robotic programs simultaneously; and recently achieved a significant milestone with the FDA approval of our VELYSTM Robotic Assistance Solution. ATTUNE ® whole knee systems, and the industry is beginning to unlock the full potential and benefits of these robotics and digital technologies, so Johnson and Johnson's medical device business has come a long way in advancing innovation. Meanwhile, the two-stage DCF is priced at $\$ 239.54$ per share, which is relatively higher than the current market value ( $\$ 164.53$ before September

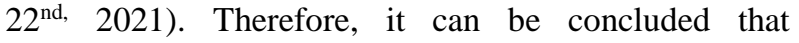
Johnson\&Johnson's growth prospects are good and that prices are likely to rise based on business presentations and historical data from the financial reports of the past five years.

\section{REFERENCES}

[1] Bodie, Z., Kane, A., \& Marcus, A. J. (2012). 18. In Investments (pp. 595-596). essay, McGraw-Hill Education.

[2] Bancel, F., \& Mittoo, U. R. (2014). The Gap between the Theory and Practice of Corporate Valuation: Survey of European Experts. Journal of Applied Corporate Finance, 26(4), 106117. doi:10.1111/jacf.12095. 
[3] Lucio Cassia, Andrea Plati and Silvio Vismara (2007). Equity valuation using DCF: A theoretical analysis of the long-term hypotheses. Investment Management and Financial Innovations, 4(1).

[4] Fernandez Pablo, 2011."WACC: Definition, misconceptions and errors,"IESE Research Papers D/914, IESE Business School.

[5] Saha, Atanu and Malkiel, Burton G., DCF Valuation with Cash Flow Cessation Risk (November 13, 2015). Journal of Applied Finance (Formerly
Financial Practice and Education), Vol. 22, No. 1, 2012, Available at SSRN: https://ssrn.com/abstract=2690292.

[6] Van BINSBERGEN, J. H., GRAHAM, J. R., \& YANG, J. (2010). The Cost of Debt. The Journal of Finance, 65(6), 2089-2136. doi:10.1111/j.15406261.2010.01611.x. 